\title{
iImplementasi Media Pembelajaran YouTube Retorika Dakwah Pendidikan Berbasis Pendekatan Ilmiah di Universitas Muhammadiyah Purworejo ${ }^{1}$
}

\author{
Umi Faizah, Mohammad Fakhrudin, Bagiya \\ Universitas Muhammadiyah Purworejo \\ umifaizah84@gmail.com
}

\begin{abstract}
ABSTRAK
Tujuan penelitian ini adalah untuk 1) mendeskripsikan penerapan media pembelajaran YouTube berbasis pendekatan ilmiah pada Pembelajaran Retorika Dakwah Pendidikan di Universitas Muhammadiyah Purworejo dan 2) mendeskripsikan respon mahasiswa pada penerapan media pembelajaran YouTube berbasis pendekatan ilmiah pada Pembelajaran Retorika Dakwah Pendidikan di Universitas Muhammadiyah Purworejo. Metode penelitian ini adalah kualitatif deskriptif yang dilengkapi dengan langkah-langkah pembelajaran ilmiah. Penerapan media ini dilakukan pada mahasiswa semester IV Program Studi Pendidikan Bahasa dan Sastra Indonesia Universitas Muhammadiyah Purworejo Tahun Akademik 2016/2017. Hasil dari penelitian ini adalah 1) penerapan media pembelajaran YouTube retorika dakwah mahasiswa semester IV Program Studi Pendidikan Bahasa dan Sastra Indonesia Universitas Muhammadiyah Purworejo Tahun Akademik 2016/2017dengan pendekatan ilmiah yang meliputi mengamati, menanya, mengeksplorasi, mengasosiasi dan mengomunikasikan terbukti efektif; 2) mahasiswa semester IV Program Studi Pendidikan Bahasa dan Sastra Indonesia Universitas Muhammadiyah Purworejo Tahun Akademik 2016/2017 memberikan respon positif terhadap penggunaan media pembelajaran YouTube berbasis pendekatan ilmiah.
\end{abstract}

Kata kunci : Media Pembelajaran, Pendekatan Ilmiah, Retorika Dakwah Pendidikan

\section{PENDAHULUAN}

Mahasiswa memerlukan wadah untuk berekspresi baik secara lisan mupun tertulis. Memiliki kemampuan berbicara tidak semudah yang dibayangkan. Tidak jarang pakar yang mahir dalam menuangkan gagasannnya dalam bentuk tulisan, tetapi asi resmi dengan menggunakan Bahasa Indonesia yang baik dan benar memerlukan latihan dan bimbingan yang intensif, keberanian, dan kecerdasan. Berbicara sebagai aktivitas di depan umum perlu dilatih agar menjadi pembicara andal.

\footnotetext{
${ }^{1}$ Faizah, Umi. Fakhrudin, Mohammad., Bagiya. 2018. "Implementasi Media Pembelajaran YouTube Retorika Dakwah Pendidikan Berbasis Pendekatan Ilmiah di Universitas Muhammadiyah Purworejo". Seminar SAGA Universitas Ahmad Dahlan 2018. preprint
} 
Seorang mahasiswa sebagai calon ilmuwan yang sering terlibat dalam kegiatan resmi harus mampu berbicara dengan baik, misalnya bertanya dalam kelas, berdiskusi, mengikuti seminar, berceramah, berpidato. Seseorang yang memiliki keterampilan berbicara yang baik akan mudah bergaul di mana pun. Dengan keterampilan yang dimilikinya, pesan akan mudah tersampaikan. Orang yang terampil berbicara akan menguasai massa. Pemahaman tentang segala aspek yang berkaitan dengan kompetensi berbicara perlu dilakukan dalam dunia pendidikan.

Ada hubungan yang mendalam antara aktivitas berbicara dengan menyimak. Berbicara dan menyimak merupakan kegiatan komunikasi dua arah yang langsung serta merupakan komunikasi tatap-muka atau face-to face communication (Brooks, 1964: 134). Ujaran (speech) biasanya dipelajari melalui menyimak dan meniru (imitasi), contoh atau model yang disimak atau direkam oleh sang anak sangat penting dalam penguasaan kecakapan berbicara. Meningkatkan keterampilan menyimak berarti membantu meningkatkan kualitas berbicara seseorang (Tarigan, 2008: 4).

Pembelajaran retorika atau keterampilan berbicara di depan umum di dunia pendidikan dapat ditempuh dengan jalan menyimak media pembelajaran terlebih dahulu. Retorika adalah seni berkomunikasi secara lisan yang dilakukan oleh seseorang kepada sejumlah orang secara langsung dengan bertatap muka. Selanjutnya retorika yang dilaksanakan di dunia pendidikan disebut sebagai retorika pendidikan. Retorika dakwah yang menjadi ciri mahasiswa Islam yang bisa disebut sebagai retorika dakwah.

Selanjutnya, retorika dakwah Pendidikan adalah pembelajaran mata kuliah berbicara dengan fokus aktivitas retorika dakwah. Sebagai contoh dalam mata kuliah Retorika di Universitas Muhammadiyah Purworejo. Salah satu kompetensi dasar dari retorika tersebut Retorika dakwah pendidikan dilakukan di dalam proses pembelajaran di kelas. Retorika ini dapat dilakukan dengan pembelajaran terintegrasi dengan kegiatan menyimak.

Pembelajaran retorika dakwah pendidikan dengan dukungan media pembelajaran diintegrasikan dengan pendekatan ilmiah untuk lebih memudahkan mahasiswa dalam pembelajaran. Pembelajaran dengan pendekatan ilmiah adalah pembelajaran yang terdiri atas kegiatan mengamati (untuk mengidentifikasi hal-hal yang ingin diketahui), merumuskan pertanyaan (menanya) (dan merumuskan hipotesis), mencoba/mengumpulkan data (informasi) dan menarik kesimpulan serta mengkomunikasikan hasil yang terdiri dari kesimpulan untuk memperoleh pengetahuan, keterampilan dan sikap. Langkah-langkah tersebut dapat dilanjutkan dengan kegiatan mencipta (Sani, 2015).

Tentang proses mengamati, Bandura (1977) menyatakan bahwa belajar observasi sebagai proses kognitif yang melibatkan sejumlah atribut pemikiran dan regulasi dari perilaku. Kegiatan pendekatan yang didahului oleh proses observasi adalah modeling. Pembelajaran melalui modeling meliputi menambahi atau mengurangi suatu perilaku yang diobservasi dan menggeneralisasikan dari satu observasi ke observasi lainnya.

Lebih lanjut, Bandura (1977) menyebut empat proses yang mempengaruhi belajar observasional yaitu 1) Atensi (attention) tahapan seseorang memperhatikan peristiwa-peristiwa secara selektif, 2) Retensi (retention) tahapan mengingat kembali perilaku yang ditampilkan oleh model yang diamati, 3) Produksi (production) tahapaan ini seseorang telah memberikan perhatian untuk mengamati dengan cermat dan mengingat kembali perilaku yang telah ditampilkan oleh modenya, berikutnya adalah mencoba, menirukan atau mempratikkan perilaku oleh model. Proses pendekatan ilmiah masuk pada tahap produksi pertama bertanya, mencoba, memonitoring, dan 
mengevaluasi, 4) Motivasi (motivation) pembelajaran melalui observasi paling efektif terjadi apabila termotivasi untuk melakukan perilaku yang ditiru (model).

Pendekatan Ilmiah lahir dengan mengadaptasi scientific learning. Istilah scientific learning diindonesiakan menjadi pembelajaran saintifik, atau disebut sebagai pembelajaran ilmiah. Dalam pengertian ini, pendekatan saintifik mempunyai ciri penanda sebagai proses pembelajaran dapat dipadankan dengan suatu proses penemuan secara ilmiah (Andayani, 2015: 375).Dalam pendekatan ilmiah, ada beberapa langkah yang harus dilakukan yaitu mengamati, menanya, menalar, mencoba, membentuk jejaring atau mengomunikasikan (Sani, 2015:53).

Media on line seperti kebutuhan masyarakat maju saat ini menjadi pertimbangan strategis dalam rangka penyusunan media pembelajaran. YouTube menjadi salah satu alternative media pembelajaran di era digital yang mudah diakses dimana saja dan kapan saja. Pembelajaran retorika dakwah pendidikan berbasis pendekatan ilmiah dapat ditempuh dengan menggunakan media YouTube. Pendekatan ilmiah dapat terintegrasi mulai dari mahasiswa mengamati film, menanya topik-topik aktual dalam film kepada dosen, mengekplorasi atau mencoba dengan memperbanyak referensi materi tentang topik pilihan yang akan dijadikan topik dakwah. Selanjutnya menghubungkan atau mengasosiasikan materi dengan dalil dari Al quran dan hadist. Selanjutnya pada tahap akhir pendekatan ilmiah adalah mahasiswa mampu mengomunikasikan atau disebut dengan beretorika dakwah dari topik yang diambil dari film religi YouTube tersebut.

\section{METODE}

Subjek penelitian adalah mahasiswa semester IV tahun ajaran 2016/2017 Program Studi Pendidikan Bahasa dan Sastra Indonesia Universitas Muhammadiyah Purworejo. Penelitian yang diterapkan adalah penelitian kualitatif deskriptif. Subjek yang diteliti adalah mahasiswa semester IV Pendidikan Bahasa dan Sastra Indonesia, Fakultas Keguruan dan Ilmu Pendidikan Universitas Muhammadiyah Purworejo. Data dalam penelitian ini berupa tuturan retorika dakwah mahasiswa. Data tersebut dikumpulkan dengan simak catat, pemilihan data yang sesuai dan pencatatan pada kartu-kartu data. Teknik validasi data menggunakan triangulasi sumber dan teknik. Teknik analisis data dengan mengkaji perspektif partisipan dengan strategi-strategi yang bersifat interaktif dan fleksibel. Komponen analisis data meliputi: (1) reduksi data yaitu penyederhanaan data yang dilakukan melalui seleksi-pengelompokkan-pengorganisasian data mentah menjadi informasi bermakna; (2) paparan data, yaitu upaya menyampaikan data secara jelas dan mudah dalam bentuk naratif; dan terorganisasi dalam bentuk kalimat (Suhadi dan Herawati, 2005).

Penerapan media pembelajaran on line berbasis pendekatan ilmiah dilakukan melalui tahapan sebagai berikut:

1) Mengamati

Pada tahap mengamati, dosen membuka halaman mengamati yang tersedia dalam media. Pada halaman mengamati terdapat video film religious yang perlu diamati mahasiswa.

2) Menanya

Pada tahap menanya, dosen mempersilkan mahasiswa untuk mengajukan pertanyaan tentang video yang telah diamati. Pada tahap ini dosen dapat membuka halaman menannya yang tersedia di media. Halaman menannya berisi intruksi kepada mahasiswa untuk menyampaikan pertanyaan, dosen dapat menekankan button untuk melihat pertanyaan yang seharusnya muncul setelah mahasiswa mengamati video. Pada tahapan ini disediakan tempat bagi mahasiswa untuk menuliskan hipotesis dari pertanyaan yang ada. 
3) Mencoba

Pada tahap mencoba, dosen membimbing mahasiswa melakukan percobaan untuk menjawab pertanyaan yang disampaikan pada tahap ini dosen dapat membuka halaman mencoba yang diberisi intruksi kepada mahasiswa untuk melakukan kegiatan mencoba. Kegiatan mencoba yang diintruksikan berupa membuat materi dakwah dari topik-topik kecil di dalam film religious.

4) Menalar

Pada tahap menalar dosen membimbing mahasiswa untuk menganalisis hasil percobaan dalam membuat materi dakwah dengan tema atau topik religious yang terdapat pada film yang telah diamati. Dosen dapat menampilkan halaman menalar yang berisi intruksi kepada mahasiswa untuk menganalisis video film religious. Pada halaman ini disertai tombol petunjuk untuk membimbing pengguna dalam menganalisis. Dosen dapat menekan button untuk menampilkan animasi yang merupakan jawaban dari intruksi yang diberikan.

5) Mengomunikasikan

Pada tahap mengomunikasikan, dosen membantu mahasiswa untuk memperoleh materi dakwah. Dosen dapat menampilkan halaman menyimpulkan yang berisi intruksi kepada mahasiswa untuk membuat materi retorika dakwah dari tahapan-tahapan yang telah dilakukan. Pada halaman ini disertai panduan pertanyaan agar mahasiswa dapat membuat retorika dakwah sesuai dengan kesimpulan yang seharusnya diperoleh. Dosen dapat menekan button untuk menampilkan simpulan dakwah yang seharusnya diperoleh atau dakwah yang seharusnya disusun. Dilanjutkan dengan praktik beretorika dakwah di hadapan teman-teman.

\section{HASIL DAN PEMBAHASAN}

1) Hasil

Pengambilan data respon mahasiswa terhadap penerapan media dilakukan setelah pembelajaran selesai. Mahasiswa mengisi angket respon mahasiswa yang berisi kolom komentar dan saran pada setiap tahapan yang terdapat di dalam media pembelajaran. Data respon mahasiswa diperoleh dari angket yang diberikan pada akhir pembelajaran. Data yang diperoleh berupa data kualitatif. Rekapitulasi respon mahasiswa dapat dilihat pada tabel 1.

Berdasarkan data angket diperoleh hasil semua mahasiswa menyatakan setuju video yang disajikan pada tahap melihat atau mengamati menarik dan sesuaia dengan materi dakwah. Hal ini diperkuat dengan komentar mahasiswa yang menyatakan bahwa video yang disajikan telah disertai dengan penjelasan yang jelas. Satu mahasiswa memberikan saran agar video dilengkapi subtitle.

Pada aspek animasi diperoleh hasil bahwa semua mahasiswa menyatakan animasi yang ditampilkan sesuai dan dapat membantu pemahaman materi. Hal ini dapat dibuktikan dengan komentar mahasiswa yang menyatakan bahwa animasi yang ditampilkan sudah sangat bagus dan dapat membantu memahami materi dengan mudah. Selain itu, penggunaan animasi membuat pembelajaran tidak membosankan.

Pada aspek bahasa diperoleh hasil bahwa semua mahasiswa menyatakan Bahasa yang digunakan mudah dipahami. Mahasiswa berargumen bahwa Bahasa yang dipakai lugas dan logis sesuai dengan Bahasa Indonesia yang baik dan benar sehingga mahasiswa dapat memahami dengan mudah. Mahasiswa lain menambahkan bahwa Bahasa yang dipakai sudah komunikatif. 
Tabel 1. Rekapitulasi Data Kualitatif Respon Mahasiswa

\begin{tabular}{|c|c|}
\hline Aspek & Keterangan \\
\hline Video & $\begin{array}{l}\text { - Video yang } \\
\text { disajikan sudah } \\
\text { menarik } \\
\text { - } \text { Isi sudah sesuai, } \\
\text { tetapi alangkah } \\
\text { lebih baiknya pada } \\
\text { video diberi } \\
\text { translate, jadi } \\
\text { ketika suara tidak } \\
\text { muncul kita dapat } \\
\text { membaca } \\
\text { translatenya }\end{array}$ \\
\hline Animasi & $\begin{array}{l}\text { - Animasi yang } \\
\text { ditampilkan sudah } \\
\text { sesuai dengan } \\
\text { materi } \\
\text { - Animasi sudah } \\
\text { bagus dan dapat } \\
\text { membantu materi } \\
\text { dengan mudah } \\
\text { - Sangat membantu } \\
\text { karena tidak } \\
\text { membosankan }\end{array}$ \\
\hline Bahasa & $\begin{array}{lr}\text { - } & \text { Bahasa yang } \\
\text { digunakan mudah } \\
\text { dipahami oleh } \\
\text { mahasiswa dengan } \\
\text { Bahasa Indonesia } \\
\text { yang baik dan } \\
\text { benar } \\
\text { - Mudah dipahami } \\
\text { karena } \\
\text { menggunakan } \\
\text { Bahasa yang } \\
\text { komunikatif }\end{array}$ \\
\hline Materi & $\begin{array}{l}\text { - Materi yang } \\
\text { disajikan mudah } \\
\text { dipahami dan lebih } \\
\text { efektif } \\
\text { dibandingkan } \\
\text { dengan buku }\end{array}$ \\
\hline
\end{tabular}




\begin{tabular}{|c|c|}
\hline & \begin{tabular}{lr} 
- Materi & yang \\
disajikan & dapat \\
dipahami & \\
ditambah & dengan \\
tampilan & video \\
animasi & \\
- Materi & yang \\
disampaikan & \\
didukung & oleh \\
animasi sehingga \\
\multicolumn{2}{l}{ mudah dimengerti }
\end{tabular} \\
\hline $\begin{array}{l}\text { Lain- } \\
\text { lain }\end{array}$ & $\begin{array}{llr}\text { - } & \text { Teori yang } \\
& \text { dijelaskan mudah } \\
\text { dipahami } & \\
\text { - } & \text { Media sangat } \\
\text { menarik } & \text { dan } \\
\text { cocok untuk } \\
\text { pembelajarn di } \\
\text { rumah }\end{array}$ \\
\hline
\end{tabular}

Pada aspek materi diperoleh hasil bahwa semua mahasiswa menyatakan materi yang disajikan dapat dipahami. Hal ini dapat diperkuat komentar mahasiswa yang ada dalam media pembelajaran.

Proses selanjutnya yaitu mengupload ke media YouTube media pembelajaran retorika dakwah pendidikan dengan langkah-langkah sebagai berikut:

1. Miliki akun terlebih dahulu dengan alamat email

2. Selanjutnya login terlebih dahulu

3. Kemudian klik histori bergambar video

4. Pilih video yang akan diunggah (dalam hal ini video yang berisi media pembelajaran berbasis pendekatan ilmiah)

5. Isi judul dan deskripsi

6. Proses unggah file media pembelajaran retorika dakwah pendidikan berbasis pendekatan ilmiah

\section{2) Pembahasan}

Berdasarkan analisis respon mahasiswa terhadap masing-masing aspek dapat disimpulkan bahwa secara keseluruhan media layak digunakan. Hal ini menunjukkan bahwa penerapan media dalam pembelajaran memperoleh respon yang baik bagi mahasiswa. Hasil analisis ini didukung oleh komentar mahasiswa terhadap media secara keseluruhan yang menyatakan bahwa semua aspek tersaji secara seimbang dan saling melengkapi. Mahasiswa lain menambahkan bahwa media pembelajaran berbasis pendekatan ilmiah mempermudah mahasiswa dalam memahami materi dan memiliki keterampilan berbicara atau beretorika dakwah. Media pembelajaran retorika dakwah pendidikan juga bisa dipelajari di rumah yang menjadikan mahasiswa lebih mudah dalam berinteraksi dengan media. Mahasiswa merasa lebih mudah belajar di rumah dengan akses YouTube. Mereka merasakan dampak adanya peningkatan kompetensi berbicara 
dakwah atau beretorika dakwah setelah mereka mengakses pembelajaran secara on line di rumah. Mereka lebih mendalami materi dan media setelah sampai di rumah.

\section{SIMPULAN}

1) Penerapan media pembelajaran YouTube retorika dakwah mahasiswa semester IV Program Studi Pendidikan Bahasa dan Sastra Indonesia Universitas Muhammadiyah Purworejo Tahun Akademik 2016/2017dengan pendekatan ilmiah yang meliputi mengamati, menanya, mengeksplorasi, mengasosiasi dan mengomunikasikan terbukti efektif;

2) Mahasiswa semester IV Program Studi Pendidikan Bahasa dan Sastra Indonesia Universitas Muhammadiyah Purworejo Tahun Akademik 2016/2017 memberikan respon positif terhadap penggunaan media pembelajaran YouTube berbasis pendekatan ilmiah.

\section{DAFTAR PUSTAKA}

Andayani. (2015). Problem dan Aksioma: dalam Metodologi Pembelajaran Bahasa Indonesia. Yogyakarta: Deepublish.

Bandura, A. (1977). Sosial Learning Theory. Englewood Cliff, NJ: Prentice Hall.

Brooks, N. (1964). Language and Language Learning. New York: Harcour Brace\& World, Inc.

Kurniawan, R.B. \&Agus. S. "Penerapan Media Pembelajaran Berbasis Pendekatan Ilmiah pada Pokok Bahasaan Hukum Newton untuk Siswa SMA Kelas X dengan Bantuan Macromedia Swishmax. Dipublikasikan dalam Seminar Nasional Fisika dan Pembelajarannya tahun 2015.

Satori, Djam'an dan Komariah Aan. 2010. Metode Penelitian Kualitatif. Bandung: Alfabeta.

Sani, R.A. (2015). Pembelajaran Saintifik untuk Implementasi Kurikulum 2013. Jakarta: Bumi Aksara.

Tarigan, H.G. (2008). Berbicara sebagai Suatu Keterampilan Berbahasa. Bandung: Angkasa.

Wisudariani, N.M.Rai, dkk. (2013). "Pengembangan Bahan Ajar Mata Kuliah Berbicara II Berbasis Pendidikan Karakter di Jurusan Pendidikan Bahasa dan Sastra Indonesia, Undikshasingaraja. e-Journal Program Pascasarjana Universitas Pendidikan Ganesha, 2. 